\title{
THE CHALLENGES OF PUBLIC UNIVERSITY INFORMATIZATION
}

\author{
Andrzej ZAJKOWSKI*, Janusz STAŃCZAK** \\ Warsaw University of Technology, Information Center, Warsaw, Poland \\ *e-mail: andrzej.zajkowski@pw.edu.pl \\ **e-mail: janusz.stanczak@pw.edu.pl
}

\begin{abstract}
The public university is a peculiar mix of features of corporations, public office, and the legacy of a tradition of federalism and academic freedom. Hence its programming information, understood as the primary management tool, requires a specific approach. This article (on the nature of the study) discusses the challenges of research by referring to selected participating (action research) carried out in the course of the implementation of information technology (IT) projects at the Warsaw University of Technology in the years 2013-15. Computerization of university is a complex, ongoing process, which depends on many factors, limited all kinds of regulations that requires making the right decision at every stage. The introduction of standardized and business processes is expensive and associated with organizational changes. However, it brings benefits in terms of new technologies, reduce operating costs and increase flexibility to respond to changing external conditions. Informatics is a dynamic process, that usually lasts as long as the organization works and develops. Organization and her environment are changing, it requires to adapt hardware and software solutions [2].
\end{abstract}

Keywords: public university, the strategy, the strategy of informatization, computerization program, enterprise architecture, IT service management, information systems and technology, operational model, project management.

\section{The specificity of public universities and its operation}

The university is a public institution that shall carry out the functions of research, educational, social, and cultural. It is a campus in which the students are educated, the future elite of society, and research center and Advisory Committee. Public school "functions at the same time according to the laws and rules of the market. Thus inherently significantly differs from both entities only public and only business entities. In addition fulfill, special social role full genetic centuries University tradition, which means specific relationships with a very wide range of stakeholders" [10].

\subsection{Higher education environment and environmental guidelines}

The university operates in an environment of higher education according to the rules that are defined by the provisions, mainly higher education act. They shall be governed by formal rules and environmental guidelines, for example, The Conference of Rectors of Academic schools in which are the subnational initiatives of the universities in Poland. They have an impact on government documents and regulations. An example is "The developdevelopment of higher education Strategy 20102020-environmental project" [12], which together with the other public suggestions reflected in the "Programme for the development of higher education and science for the years 2015-2030" [5] developed by the Polish Ministry of Science and Higher Education.

The document contains guidance in directions of the development of higher education and science, in particular aspects of improving the quality of education and adapt it to the needs of society, improve the quality of research, changes in organization management and financing, and increasing the impact on the environment (social, economic, and international).

In each of these aspects, this paper puts a strong emphasis on cooperation with foreign institutions. In accordance with the guidelines of the Warsaw University of Technology (WUT), their essential internal documents have developed. 


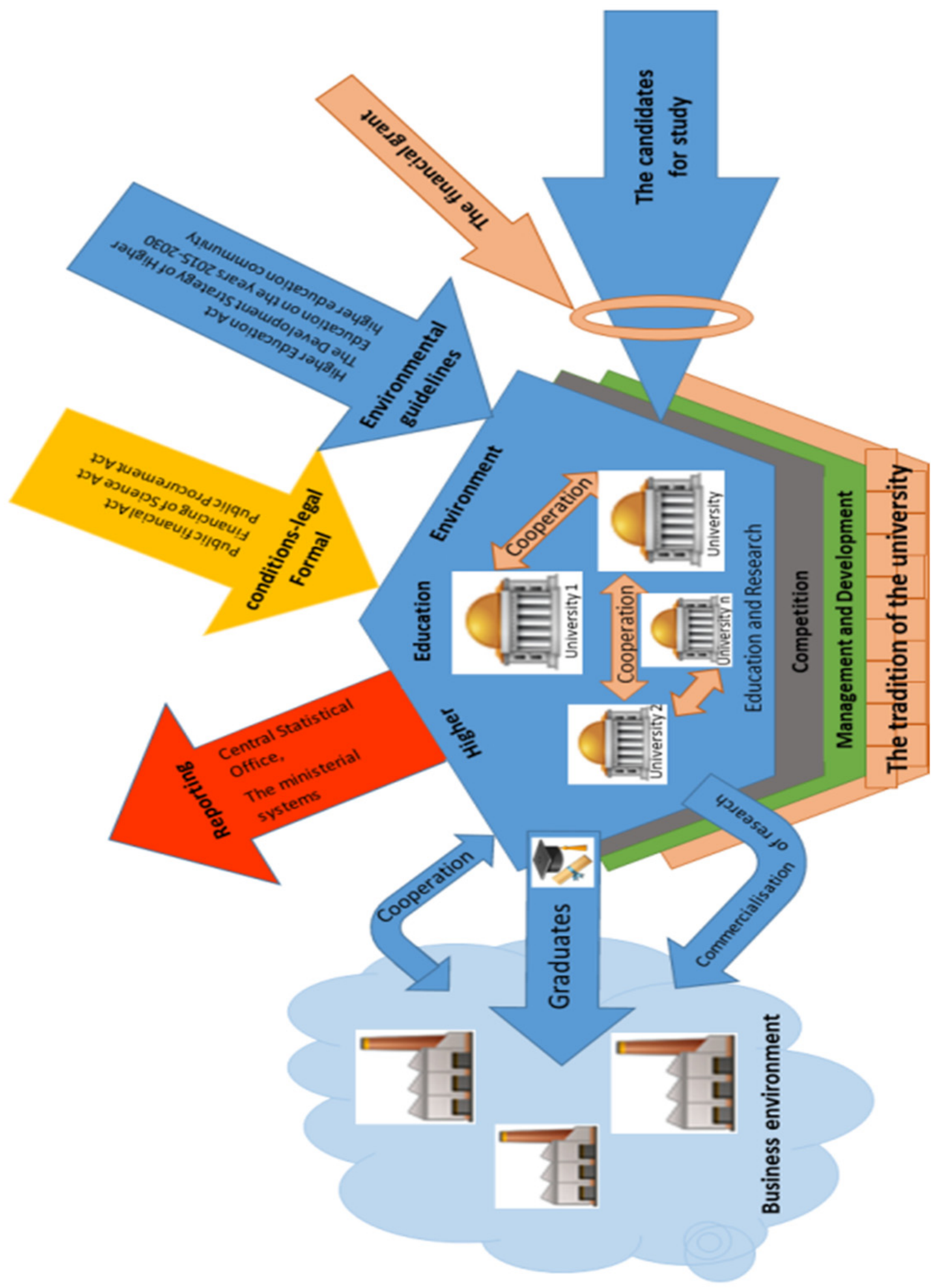

Figure 1 . The context of the functioning of the University (source: own elaboration) 
They are the following:

- The Mission of the Warsaw University of Technology, which outlines the vision plans and their implementation within the framework of the education and research, taking into account the needs and directions of the development of society in conjunction with the prosocial university tradition,

- The Statutes of the Warsaw University of Technology, setting out the General principles of the functioning and organization of the College,

- The Warsaw University of Technology Development Strategy up to 2020, that indicates the development in four key areas of its activities: education, research and the commercialization of research results, the university's interaction with the environment, organization and management.

\subsection{Formal conditions - legal}

In addition to the environmental conditions, the WUT is a public entity and subject to the legal rules in this sector. It is required to conduct its business in accordance with the applicable legislation. Specific public finance act is here applicable, the financing of science and public procurement act. These are the tools of state bodies for the proper and effective management of public assets. A specific role that organizes and, unfortunately, limits the freedom of action, is the if public procurement act, which serves the implementation of purchases of goods and services subject to the requirement for competitiveness.

\subsection{Measurement of competition}

"The market economy is associated with competitiveness, and this also applies to higher education" [1]. Universities compete in our quest for the best candidates for the students, the best scientists, most grants, etc. "The competitiveness between them occurs not only in the field of science and teaching, but also in services to the economy, government, nongovernmental organizations" [3, p. 74].

Despite operating in a college environment, under which the universities and their faculties receive a financial subsidy from the state budget to carry out statutory activity, at the same time, work in the sphere of the market economy must meet its rules. They are forced to compete with other universities for students. The competition takes place in multiple dimensions (the attractiveness of studies, conditions of the student life, the scholarships, the university's position, attractiveness directions and ability to acquire interesting and well paid job, the possibility of doctoral studies and subsequent career, international exchanges, technological advancement, professional internships, etc.).

The competition is so much stronger, as nonpublic universities also participate, which often have a close, very business, profile. They are not constrained by provisions relating to public bodies and are better prepared to compete.

Competition in the field of education, but rather to obtain the greatest number of students, is so important that universities receive special subsidy depending on the number of students. In the context of the demographic decline, it is important because the acquisition of students becomes increasingly difficult.

In the research on the competition, in addition to private universities, there is the typical research centers that specialize in specific segments of the science. Competition in the field of research affect the number of obtained orders from the economy, which entails financial benefits and creates prestige.

\subsection{The tradition of university}

Independence and university tradition are still carefully cultivated in the public schools. This is the legacy that integrates academic life and is an important cultural message in shaping personality. It strengthens the academic community and affects the image and prestige of the social [10]. It is believed that "centuries-old tradition of the university is one of the highest forms of civilization achievements of humanity. (...) Public school gets so to twofold challenges. First, keep the tradition. (...) Secondly, social expectations about a high level of social aspiration to achieve individual and collective" [3, p. 78].

Tradition manifests itself in many aspects of university life, affects the implementation of the activities and processes helps to fill cultural functions, whether educational opinion-makers. It is the most important 
and natural part of the university's brand. Tradition makes college life richer and fuller, but processes and the scope of the operation of the colleges make students little susceptible to change. This is particularly important in the reorganization and optimization of processes and the implementation of modern information technology (IT) solutions, which has a significant impact on the ability of universities to the modern trends of development and their pace.

\subsection{Public reporting}

The university similar to every other public entity is required to report to the public information and the parent institutions in terms of statutory activity, financial reporting, statistics declarations, and notices of public contracts. In the past five years, recognizing the need to increase the efficiency of management and financing of higher education, in accordance with the "Programme for Development of Higher Education and Research for the years 2015-2030" [5], by the Polish Ministry of Science and Higher Education requires from college even wider reporting of business activity - substantive (e.g., human resources, degree courses, and scientific achievements) and on the economy of their own (e.g., investments, the properties owned, and their use).

Support is a nationwide system of POL-on. If the university is bigger and has a more complex structure and the degree of independence the departments is greater, it is more difficult to perform these duties. In order to meet the vital importance of building a uniform system of reporting within the framework of an integrated IT systems that supports the management of the institution.

\subsection{The university as the office, or public duties}

Although it sounds iconoclastic in the context of university traditions, the current rules make the university, as a public body, to officially adopt the typical functions and behaviors. It is committed to customer services, which are mainly students, to administrative proceedings in accordance with the laws of the duties and tasks of public entities, to provide public information about their busi- ness. Such behavior also determines the shape and functioning of IT resources.

The university is required, for example, in accordance with the law on IT for bodies pursuing public tasks, for sharing your secure electronic inbox, meeting the standards defined by the proper Minister of Information Technology. Similarly, the university is obliged to carrying out the public information bulletin.

\subsection{Cooperation with the environment}

Cooperation may be considered at several levels. An important element of it is tracking the fate of graduates. This can lead to cooperation (technical, industrial, economic, educational) between alumni and employers who employ them and university, from which both parties will benefit.

Cooperation with the economic environment drives and inspires research centers, including public universities, to undertake specific research directions. It ensures that specific productions problems are solved, new technologies are implemented, the modern materials are developed.

Cooperation with the business environment brings benefits to the university, in addition to the financial prestigious. In the university environment, specialized centers are created, whose job is to seize the handle of the process of commercialization of research results. An example is the WUT Innovation Management and Technology Transfer's Centre financed from the resources of the European Union.

\subsection{The university as a corporation, or condi- tions in the management and development}

Higher public college is essentially a nonprofit institution (perhaps in a limited range of provisions to make money on the services, but as a whole must develop to cover the costs of activities and development), though organizationally it reminds economic corporations, especially those traditional, heavily burdened with fixed costs related to infrastructure and an extensive staff and social services.

Meanwhile, the competitive position is always connected with the possibilities of development. In the light of the described significant fixed costs, the challenge is an appropriate change in the approach to the management of the university. It is 
necessary to seize the market rules of management processes, but in a way that does not destroy the tradition, and prestige. Investments are necessary, especially in the IT solutions that will facilitate these processes, while, at the same time, will increase the attractiveness of studying and research potential, thanks to the use of modern technology.

Way forward is particularly centralization of common services, including IT, because it prevents the dissipation of the cost of services, which "do not see" and the efficiency of their supply is low. This is in conflict with a natural devolution to conduct of education and research. Finding a solution to this conflict, which is possible, promotes the latest trends of economic development, putting emphasis on a pedestal intellectual capital and innovation, which should be introduced with caution "using the concept of A. Giddens" - traditional school is orientated towards the past, where the words of the past in the form of ritual and symbolic policy has overwhelming influence on the present or future control task 'be harnessed' through the prism of the burden of the past. “(...) Therefore, the space of traditional teachings with such difficulty is critical of modernization, commercialization and technicality" [4].

\section{Characteristics of the baseline}

In accordance with the Polish Programme Development of Higher Education and Science for the years 2015-2030" ".. an important element of the reform should be to make a base unit of the University, and not the Department. In the current legal framework universities are rather federations of departments assessment bodies, accreditation, permission to give degrees. The changes, backed up by funding mechanisms, should lead to increased interdisciplinarity and flexibility of constructing learning pathways, to break the mutual isolation of faculties and the optimal use of the resources of the University." [5]

Organization of faculty autonomy means that the current environment management solutions are characterized by a high level of decentralization and, in the field of IT solutions, a variety of technologies and standards.

The level of standardization is, unfortunately, quite different from the minimum to ensure that the uni- versity economically justifiable to support its activities. The main problems are:

- too high baskets the maintenance and development of IT systems on a scale of universities and limited ability to control funds allocated for this purpose,

- restrictions on the exchange of data between departments and access to current data,

- uncontrolled from the level of IT center redundant data,

- insufficient quality of IT services resulting from the lack of a mature and modern organization to support these services,

- the lack of a clear determination and consistent application of standards, especially in the absence of a definition of corporate architecture resources and IT services,

- duplication of functionality in different systems,

- diverse and, in most cases, insufficient level of security of information and communication systems, resulting from the absence of homogeneous and consistent safety standards,

- limited ability to implement initiatives in the field of information and communication services for the coverage beyond a single frame of the faculty of the university,

- limited ability to planning development systems of information and communication services from a level of university [11].

Fulfilling the role of the college, among others, is the use of IT, which is crucial to improve both the quality and efficiency of the implementation of tasks and the attractiveness of the services provided by universities.

One of the elements that have an impact on the final effect of the implementation and use of IT is an organization of information services departments, their location in the universities structure, and processes and cooperation with its administrative, teaching, and scientific units, for which IT support built the implemented processes.

Ordering the organization in the use of IT services, which are changes in the entire public administration, aimed at stepping up electronic caller's service projects and the exchange of electronic information, 
including replacing paper document with an electronic document. Process of change also enforces the external environment, in the form of, among others, various reporting, taking into account the requirements of inter-operability.

In addition to the environment and determinants of university activities that are shown earlier, the following are the characteristics of the challenges in the IT field, in particular for e-Government and eservices.

\subsection{Selected items of the document "State 2.0"}

The key to the success of the changes in the organization of the conclusions come from a report of the Ministry of Administration and Digitization of The report "The State 2.0.". A new start for eGovernment (2012) [7]. The report had two goals. First of all, a synthetic information on the status of implementation of projects relating to information technology and digitalization. Second, it presented guidelines for further action in the field of computerization and digitization of Polish, with a particular focus on the development and improvement of eGovernment.

A large part of the irregularities in the computerization of the different fields of activities and the implementation of individual projects has its origin in the incorrect assignment of roles. In particular, this applies to projects in which the departments of computer science take over all roles, including owner, or principal unit of competent in matters of organization and management and legally responsible. Meanwhile, remember that process owners need to see the entire string action and then detail the role of IT in the process, and reasonable information is able to define and supervise only one who this information needs. It is so processes in public entities (colleges) and services they provide.

The owner of each process should be so no programmer, but substantively engaged employee who really is responsible for the process. Passive attitude of the people actually responsible for the area of the organization that leads mostly to define requirements and abnormal business justification, as well as the excessive costs of computerization. The same quality of IT projects leading to the creation of information systems and computer scientists, not choosing IT specialist, but experts in the field. They have knowledge on purpose facing the organization (the report "The State of Web 2.0", 2012).

\subsection{The Program Integrated Informatization of The State (PZIP)}

PZIP [6] is a strategic document that describes the actions of the government's efforts to provide the public with high-quality electronic public services. The objective of the program is the preparation of a coherent, logical, and efficient information system of the state, delivering e-services at national and European level, in an efficient manner in terms of quality and cost.

The program will provide the cooperation of existing and new information and communication systems of the public administration, while eliminating redundant functionality yet. By filling the objectives PZIP will measure the percentage of citizens and businesses benefiting from e-government services, and the level of user satisfaction [6].

The document stresses that the "current process of computerization of island characterized by solutions that match the needs of the various sectors of public administration, however, did not provide sufficient interoperability of systems, which could have a negative impact on the implementation of eservices. In the light of the above, it has become necessary to introduce a new instrument for planning and coordination of information technology for public entities, that is, established by resolution of the Council of Ministers" [6] (The Program Integrated the State Informatization, 2014). The essential thing that it lacks of is that it does not deal with the place and the role of the departments IT services in organization.

There is no reference to the issue of the standardization organization, which can be a source of failure in maintaining and implementing next IT tools in the longer term. In particular, this may cause further construction of isolated systems supporting only a single business process, so that the later integration is more labor-intensive and expensive [8]. 
The same is true in many universities. IT support, pursue almost isolated cells in basic units of the University, using a variety of solutions, would not ensure interoperability, which leads to a different support similar processes.

Meanwhile, the integrated computerization is based on four pillars:

- Logical and efficient circulation of information that makes the administration to help the citizen (in the university, employee or student) in the execution of his/her obligations to the state or the university and assisted him/her in carrying out his/her aspirations. Computerization is, therefore, subordinated to the circulation of information.

- Focus on the processes and services it provides, rather than on projects. The owner of each process is a public authority (the university) by an official body, which is really responsible for the contacts on the lines of the state's citizen (student).

- Transparency and effectiveness in expending public funds. All selected and implemented solution must guarantee the best possible results to relationship effort involved.

- Technological neutrality, which ensures that access to services and supplies for administration (university) is not restricted to use technology and results only from the functional needs. Selection of solutions provides the possibility of future changes to the IT solution provider, if the cooperation with the present does not guarantee the fulfillment of the expectations of the public site [6].

\subsection{State Enterprise Architecture: support for interoperability of public administration}

Development of European Reference Architecture for Interoperability [15] is a project layer to increase the interoperability of pan-European and the development of corporate architecture of the Polish State (increasing cross-border and cross-sectoral stocktaking exercise interoperability Polish solutions), including the use of already existing solutions, in accordance with the EIRA. In both cases, it is assumed that the main tool would be the uniform description of electronic public services in the EU (architectural construction blocks).

The effects of the project are:

- electronic public services: a common methodology and terminology of the description of services, their components and interfaces, and the rules for the exchange of data between services,

- to facilitate the design and construction of services using other solutions reduce costs,

- discovering candidates for shared services, solutions available for re-use; comparing solutions to optimize them,

- the reference architecture for interoperability for the segment,

- increase compliance solutions with national and the European Interoperability Framework [15].

Given the above challenges in mind, the university should have up their sleeve approved plans to computerize in view of the annual and multiannual basis, forming the basis for a consistent build an integrated information system. Its construction should be based on proven solutions and experiences of implementing them. This requires having a strategy (hereinafter the strategy) together with the appropriate organization covering both project management and systems maintenance after deployment.

A major concern is the financing of such projects. Analysis of National Operational Program indicates that it will be possible to obtain resources on, for example:

- support consolidation processes (Operational Program Knowledge, Education, and Development - POWER),

- the modernization of ICT infrastructure in organizational units (Operational Program Infrastructure and Environment, themed objective No. 6 preservation of cultural heritage and the development of cultural resources).

In the framework of the III priority axis of an Operational Program Knowledge, Education, and Development (POWER) will be able to:

- provide education at a higher level, corresponding to the needs of the economy, 


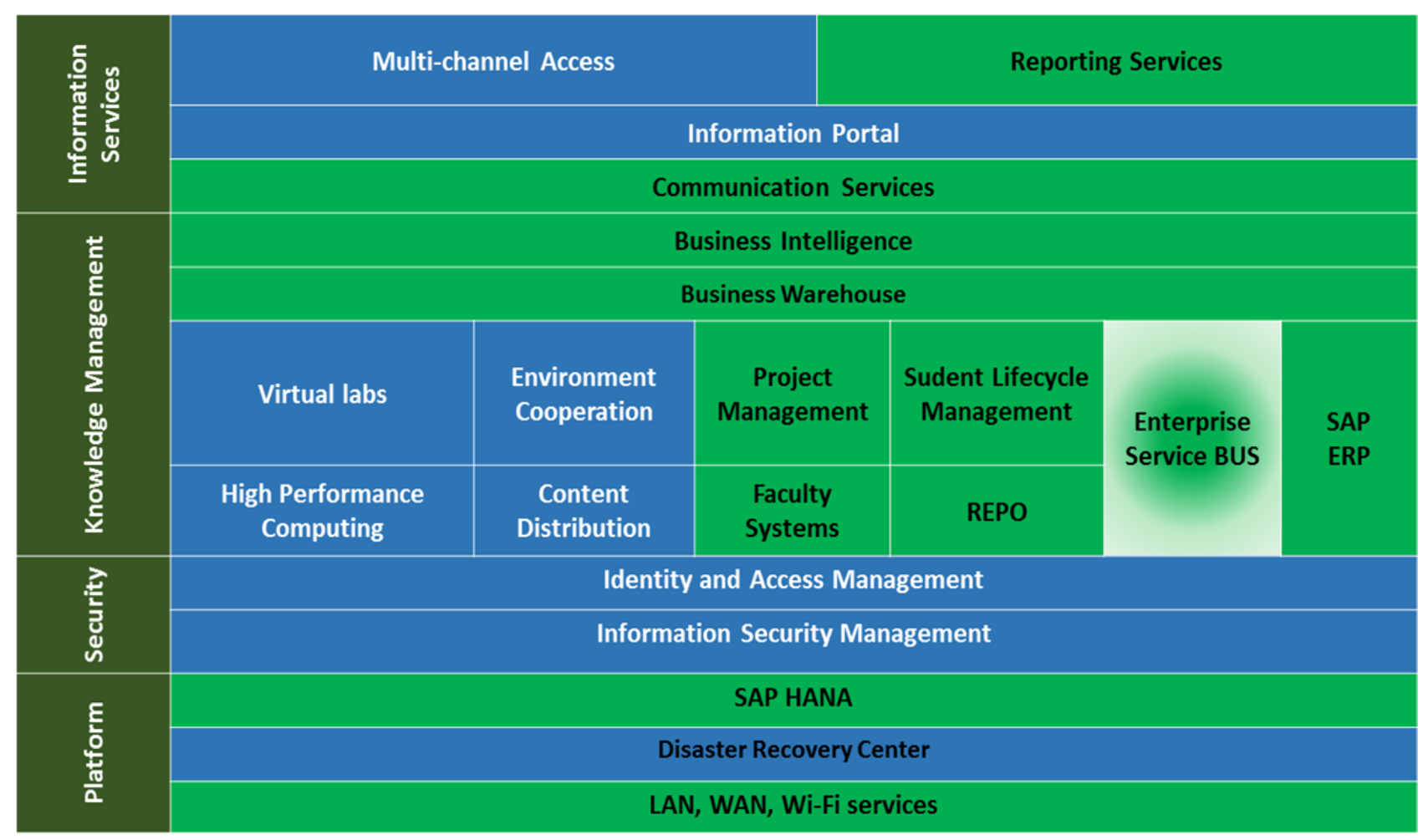

Figure 2. The vision of the integrated system (source: own elaboration)

- enhance the quality of doctoral studies and provide their participants with appropriate directions,

- increase openness and international mobility in higher education,

- improve the quality of teaching and the development of management systems on college campuses.

In the framework of the operational program Digital Poland deliver objectives such as, how to build effective and user-friendly e-services, including the area of science and higher education.

In the framework of the II Investment Project of the Operational Program, the following will be possible by Digital Poland:

- digitization of learning resources and create interactive electronic services, for example, students, researchers, entrepreneurs, public administration,

- creation of services and applications that use epublic services and public sector information.

\section{The vision of the integrated system in WUT}

Fig. 2 shows the architecture of the integrated system, which in the rest of the article will be approached by the example of the Warsaw University of Technology. The vision of an integrated system is presented based on layers, of which the construction, modernization, development, and maintenance can be reasonably independent, but which eventually will consist on the system, to ensure the provision of scheduled services on a given level, complying with the requirements, resulting, for example, modern technologies used by students, security policy (including providing continuity), or legal requirements.

There are no obstacles to attach to such a model of the architecture additional modules, especially if you have previously set out clear principles of construction based on the concept of enterprise architecture. 
From the point of view of analysis and design, there are four layers of corporate architectures (TOGAF):

- business (business architecture),

- data (data architecture),

- application (application architecture),

- technical infrastructure (technology architecture).

Enterprise architecture is understood as an arrangement of business processes and it infrastructure according to the logic that reflects the requirements for the integration and standardization of the operating model [8] and may be considered as a tool to support strategic decision making in response to the formulated previously possible paths of action. Enterprise architecture models have a wide range of applications. The following are most commonly used:

- the matching of information technology to strategic objectives of the organization,

- removal of reengineering redundant and inefficient business processes,

- an integrated approach to the creation of processes and information systems,

- change in management (including strategic change, and transformation of the organization) and development of the organization [14].

In order to ensure systematic procedures for corporate architecture frameworks for enterprise architecture are used. They should provide a coherent description of the organization; methods at the level of principles, strategic objectives, business processes, data, software systems, technical infrastructure and provide a conceptual apparatus for your enterprise architecture [14].

The purpose of the construction of an integrated system for the University will be support service processes as a result of the implementation of modern architecture, and not the hardware platform and the system. This is consistent also with the new prospect of EU funding, focusing on the effects of systems but not on their construction.

The integrated system will provide both transactional, interactive and informational services.

In accordance with the above, the vision of an integrated system for the college shall be based on the following layers:
- the platform as a member of the integrity of the organization's solutions used, from which the quality and reliability depends on access to all other services. Never so much service were dependent on this layer, in particular when using a class cloud computing solutions,

- integrating security in both business processes and functional requirements (including the law), and the organization. In particular, the major problem to be solved is the identity management and access, also due to the provision of services using a variety of technologies,

- knowledge management as a support to the implementation of the strategy, vision, mission, education, scientific research and university management through sharing: relevant data and their sections, applications and systems, based on the competences of human teams,

- information services, as the bilateral channel, universal communications based on a variety of modern technologies and personalize the needs of stakeholders.

The key to the success of the construction of an integrated system is to provide mechanisms for the supervision of information services in the University and the use of quality indicators, which in the longer term should ensure the implementation of identified priorities, at a constant optimization costs of IT services. For informatization, which should support the implementation of processes in organization, that means the need to systematically modify deployed solutions, as well as search for new, more efficient and effective for organization [2]. According to above make the universal nature of the proposed vision of architecture.

\section{The initial stage of computerization on the example of the Warsaw University of Tech- nology (WUT)}

In accordance with the vision of the integrated system as shown in Fig. 3, and the Warsaw University of Technology informatization strategy until 2020 [11], the University has consistently built integrated information platform. 


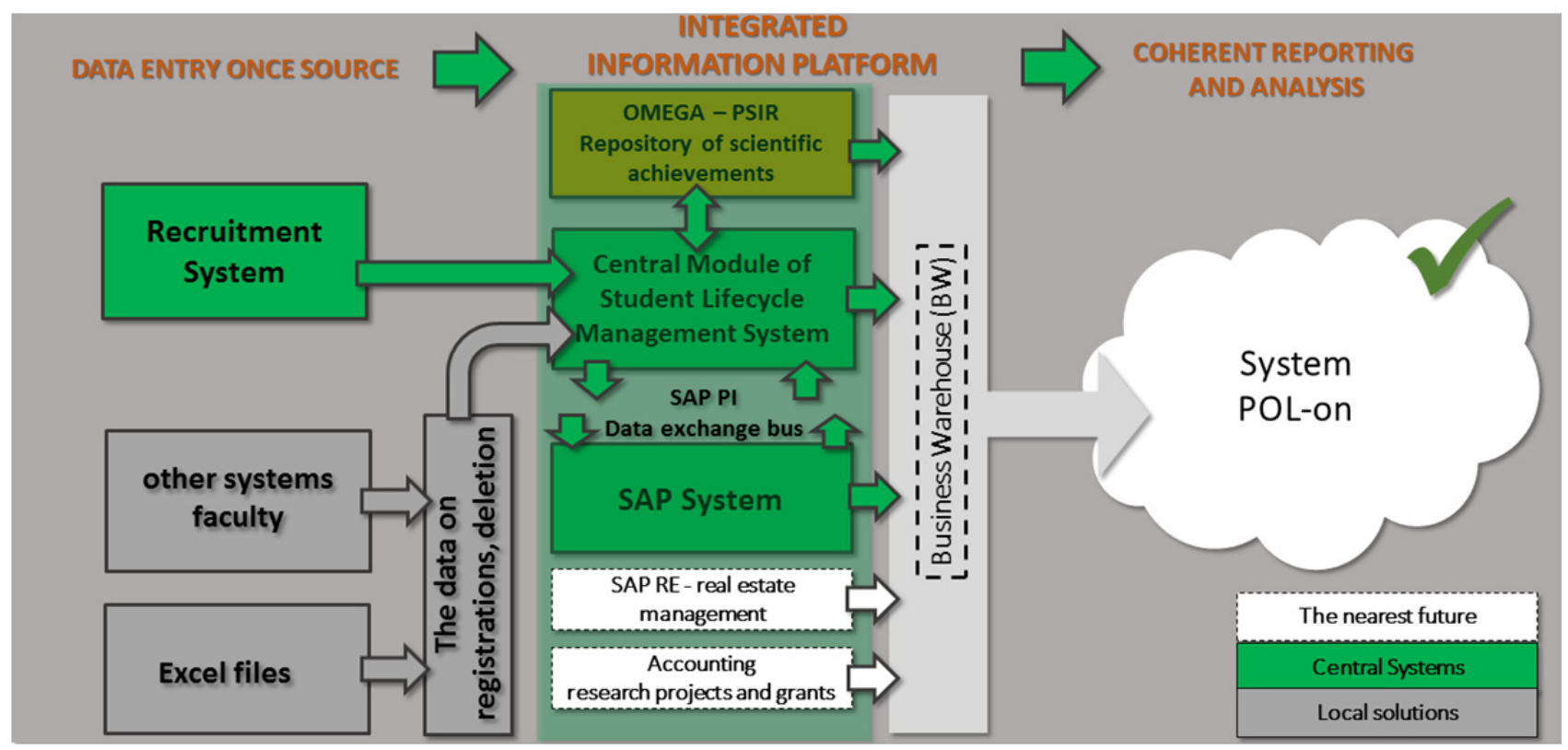

Figure 3. Integrated Platform

(source: own elaboration)

It is based on three main information systems: $\mathrm{SAP}^{1}$, USOS, OMEGA-PSIR that are the pillars of this platform [www.ci.pw.edu.pl].

The SAP system in addition to a collection of functional modules are used as resource tools (e.g., Data Exchange Bus, Business Warehouse).

Built the platform we are motivated by the following idea - data entered once and at the source, and all reports will be generated from a single location-data warehousing in SAP BW. Each implementation is carried out in a formula as a separately project involving the information services of the University, specialized external companies and numerous teams of users with different units and organizational cells WUT [10].

\section{Strategic considerations of informatics}

The implementation of information technology in universities, an organization that works with complex environment in the legal conditions and, in particular, in a business environment based on compete-

\footnotetext{
1 The project implementation of the SAP system in the area of Finance (FI) has been awarded the prestigious SAP Quality Awards 2014.

https:///www.pw.edu.pl/Uczelnia/Aktualnosci/Wreczenienagrody-SAP-Quality-Awards-2014-przedstawicielomPolitechniki-Warszawskiej
}

tion, with the financial uncertainty is high risk. As a result of the implementation of it projects, services should ensure availability and continuity, be widespread and expected by users of the service.

The success of the organization depends on a number of factors, and you have to base it on an efficient organization knows your business processes, well know management, equipped with appropriate information technologies. A particular role in developments should be served by an information technology strategy. Strategy affects the other strategies and policies of the university, and, marks lines of action out in a strict role and place it services in your organization, with well-appointed measures success.

Fig. 4 shows the improvement cycle IT services in your organization, based on the principles arising from the strategy. Define strategies in particular: the digital divide in areas; the objectives to be attained in the direction area; university IT model, will let, in the long-term mutual feedback of improvement implement of selected by Committee decision:

- computerization program,

- analyses of measurement indicators (including quality of service-related) and the results achieved now, 


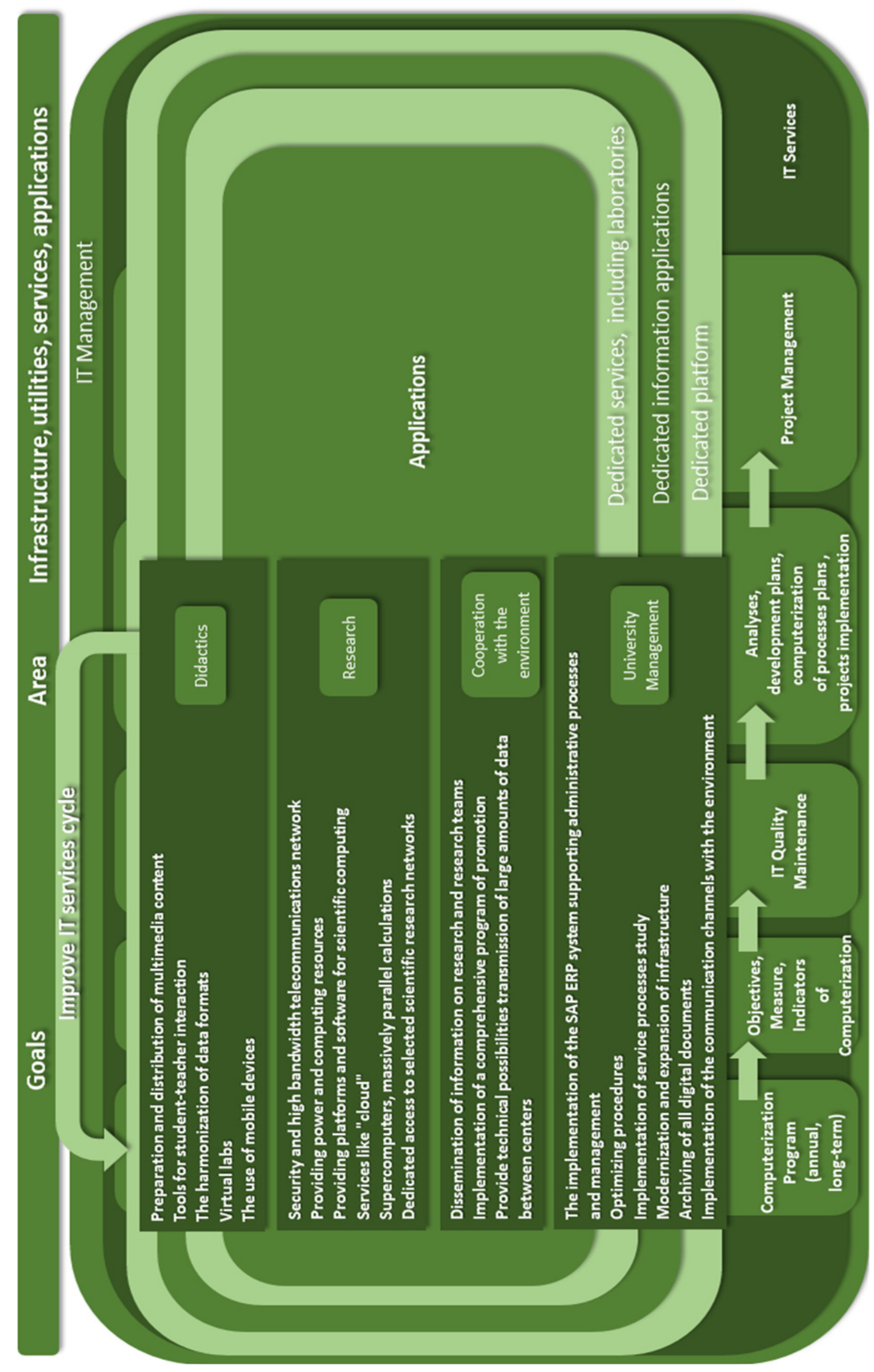

Figure 4. Series of improvement of IT services in your organization (source: own elaboration) 
- development plans adopted as a result of the analysis,

- IT projects,

- priorities (to restrictions, especially financial)

and gradually achieve the appropriate level of implemented services using infrastructure and IT tools. The complex structure of actions requires ongoing commitment to solving the problems to find such a program information technology to ensure the sustainable development of organizations.

The achievements will be evaluated using strategic indicators of information technology. In particular, the implemented services should support the processes and functioning of information technology should take place in accordance with the principle of minimizing the risk.

The management of information technology is complex, because in any case you need decision-making include:

- priorities, but restrictions and so manage financial for example (maintenance systems their own or also develop them?),

- resources (decisions: growth the competence of the teams and the level of employment),

- the availability of services and their continuity and, above all, their quality (what to adopt service level agreement, after all, dependent on many factors).

It should also be aware of the limitations of the competence of the project teams and the teams responsible for the exploitation, provide resources and training time so, primarily with significant changes of functional requirements, entailing changes in technology. Do not forget about standards, held with the aid of control non-functional requirements, in order to use an existing, familiar and infested solutions for sufficient flexibility.

We must also remember that each project forces the organizational changes, resulting in an even process optimization, which is reflected for example. in the need to update the procedures - this is so the area decision, but formal in nature.

Any decision can significantly change the status quo, while going beyond the limitations. Decisions should therefore be based on the analysis, using the knowledge in the organization, adopted standards, the experience of teams and the methodologies and good practices.

At the same time it is important to establish measures and indicators, in order to set the cycle control the quality of service, which may be the only thing an objective assessment of the results achieved.

Decision-making requires knowledge in the organization. In accordance with [8, pp. 132-133] key for building the foundation for the growing number of practices:

- centralized funding applications,

- targeting corporate architecture principles,

- standard project management methodologies,

- business justification investment in architecture,

- the process of obtaining formal approval,

- annual funding for infrastructure protection,

- the formal management of exceptions,

- official processes and the adoption of technology,

- the evaluation of post deployment,

- It is necessary to include also,

- recommendations of the audits,

- service management, in particular the quality of the services,

- risk management,

- security management,

- corporate governance,

- process management,

- rules for supervision of IT,

- non-functional requirements affecting the standards.

As indicated in [8, p. 147] and authors researches, regardless of the knowledge gathered in the organization, support the highest leadership decides significantly about building the foundations of an organization based on information technologies.

The key issues for any decision on IT [8, p. 155]:

- the principle of IT (including the role of IT in the operating model and funding IT),

- corporate architecture (including business processes, standardization of technology), 
- IT infrastructure (including infrastructure services, their pricing, update technology and outsourcing),

- business applications requirements (including measures of success),

- investments and priorities IT (including changes to processes, portfolio of projects, standardization and innovation).

When making decisions, also on the IT services, most often we meet with two categories: selection and prediction. In addition to these two main categories of decision-making issues many types of decision-making purposes, such as:

- planning,

- generate a set of options,

- setting priorities,

- choosing the best strategy,

- systems projects,

- performance measurement,

- ensuring the stability of the system,

- optimization,

- resolving conflicts.

\section{Summary}

Computer science is a flow of decisions based on knowledge of the teams and the determination of the management. IT services is not only providing technical platform, but enforcing the relevant organizational operation.

Computerization of universities should take into account the cooperation with platforms of public entities and should take into account the recommendations of the relevant documents as well. Informatization strategy should be realized in the project approach, making use of the available resources of the university, as well as in the framework of EU programme, taking into account the obligation to ensure the sustainability of the results of the projects.

Decisions that are need to take at each stage of the implementation of the information technology, should be supported exploiting the methodologies and other good practices, in particular the analysis of the pre implementation, which is the beginning of any decision. A prerequisite for the implementation of changes is the regularity of building solutions, project after project, based on the organization [13].

\section{$7 \quad$ References}

[1] Beksiak J. ([2006) - Przydatność konkurencji dla szkolnictwa wyższego. (The usefulness of competition for higher education) [w]: J. Dietl, Z. Sapijaszka (red.), Konkurencja na rynku ustug edukacji wyższej (Competition on the market of higher education), Fundacja Edukacyjna Przedsiębiorczości, Łódź.

[2] Gołuchowski J., Smolarek M. (2014) - Semantyczne modelowanie organizacji (Semantic modeling of the Organization), Difin S.A., Warszawa.

[3] Kamińska A., Zawiła-Niedźwiecki J. (2015) Koncepcja modelu polityki informacyjnej uczelni publicznej $w$ kontekście zrównoważonego zarzadzania (The concept of information policy model of public education in the context of sustainable management), [w:] Innowacje wnowoczesnych organizacjach. Aspekty ekonomiczne i spoleczne (Innovations in modern organizations. The economic and social aspects), Zeszyty Naukowe Małopolskiej Wyższej Szkoły Ekonomicznej w Tarnowie, nr 1.

[4] Ostrowski A. (2013) - Uniwersytet jako przestrzeń konfliktu wiedzy $i$ informacji. Przyczynek do analizy posttradycyjnego systemu eksperckiego (The University as the conflict knowledge and information. Contribution to the analysis of the post-traditional of an expert system). [w:] G. Nowaczyk, D. Sobolewski (red.). Marketing $w$ szkole wyższej (University 's Marketing). Poznań: Wydawnictwo Wyższej Szkoły Bankowej.

[5] „Program Rozwoju Szkolnictwa Wyższego I Nauki na lata 2015-2030" (Programme for the development of higher education and science for the years 2015-2030), MNiSW (2015).

[6] Program Zintegrowanej Informatyzacji Państwa (2013) (The Program Integrated The State Informatization), Ministerstwo Administracji I Cyfryzacji, Warszawa. 
[7] Raport „Państwo 2.0”. Nowy start dla eadministracji (2012) (The report "the State of Web 2.0". A new start for e-Government). Warszawa: Ministerstwo Administracji i Cyfryzacji, Warszawa.

[8] Ross, J.W., Weill, P. i Robertson, D.C. (2010) Enterprise Architecture as Strategy. Warszawa: Studio EMKA.

[9] Rybiński H. (red.) (2015) - Strategia Informatyzacji Politechniki Warszawskiej do roku 2020 (Warsaw University of Technology Informatization Strategy 2020), www.ci.pw.edu.pl.

[10] Stańczak J., Zawiła-Niedźwiecki J. (2015) Doświadczenia $z$ projektu wdrażania SAP $w$ Politechnice Warszawskiej (The experience of the project implementation of SAP in the Warsaw University of technology) Zeszyty Naukowe I Kongresu Informatyki Ekonomicznej, Katowice.

[11] Strategia Rozwoju Politechniki Warszawskiej do roku 2020 (The development of higher education Strategy 2010-2020) (2011), praca zbiorowa pod redakcją R. Gawrońskiego, http://bip.pw.edu.pl/.

[12] Strategia rozwoju szkolnictwa wyższego 20102020 - projekt środowiskowy (The development of higher education Strategy 2010-2020environmental project) (2009), praca zbiorowa pod redakcją Konferencji Rektorów Akademickich Szkół Polskich (KRASP), Wydawnictwo Uniwersytetu Warszawskiego, Warszawa.

[13] Sobczak A. (2009) - Modelowe ujęcie harmonizacji zarzadzania ustugami IT zarchitektura korporacyjna (Model shot of the harmonization of IT service management with corporate architecture), Roczniki Kolegium Analiz Ekonomicznych SGH, 19.

[14] Szafrański, B. i Sobczak A. (red.) (2009) Wstęp do Architektury Korporacyjnej (Introduction to Enterprise Architecture), Ogólnopolskie Seminarium Międzyuczelniane Problemy badawcze i projektowe informatyzacji państwa (Problems of research and design work to computerize State). Warszawa.

[15] Workshop: Development of European Reference Architecture for Interoperability (European Interoperability Reference Architecture/EIRA) the materials of the Department of Information Technology, Ministry of Administration and Digitalization, 2015. 